\title{
SCIENTIFIC PHYSICAL EXERCISE TO PREVENT MUSCLE INJURY IN COMPETITIVE SPORTS
}

\author{
EXERCICIO FÍSICO CIENTÍFICO NA PREVENÇÃO DE LESÕES MUSCULARES NOS ESPORTES COMPETITIVOS \\ EJERCICIO FISICO CIENTÍFICO EN LA PREVENCIÓN DE LESIONES MUSCULARES EN LOS DEPORTES COMPETITIVOS
}

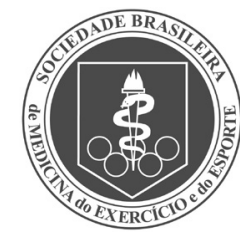

Original Article

ARTIGO ORIGINAL

Artículo Original

\author{
Delong Liu' (1D \\ (Physical Education Professional) \\ 1. Sports Department, Xi'an \\ International Studies University, \\ China.
}

\section{Correspondence}

Delong Liu

Xi'an, China, 710000.

liudelong43210@163.com

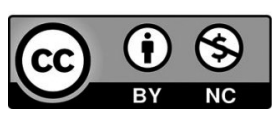

\begin{abstract}
Introduction: Various factors cause many sports traumas in groups engaged in mass sports activities, amateur sports training, and professional sports training in China that must be called to our attention. Objective: Scientific Sports Therapy is a scientific and reasonable systemic sports training program formulated for competitive athletes based on their physical and disease characteristics. Methods: This article conducted scientific sports therapy interventions on tennis elbow patients and analyzed multiple physiological indicators such as muscle endurance before and after the intervention. Results: There are significant differences in the athletes' muscle strength and muscle endurance data after physical exercise therapy. Conclusion: We analyzed the causes of muscle damage and adopted scientific and practical sports therapy. In this way, coaches and athletes can find effective ways to prevent and manage muscle injuries, thereby improving competitive sports training. Level of evidence ll; Therapeutic studies - investigation of treatment results.

Keywords: Exercise Therapy; Tennis Elbow; Sports.

\section{RESUMO}

Introdução: Vários fatores que causam muitos dos traumas em esportes nos grupos que praticam atividades esportivas de massa, treinamento esportivo amador e treinos esportivos profissionais na China devem ser o foco de nossa atenção. Objetivo: A Terapia Esportiva Cientifica é um programa de treinamento esportivo sistemático formulado para atletas de competição baseado em suas características físicas e de suas doenças. Métodos: O estudo conduziu intervenções terapêuticas esportivas científicas em pacientes com cotovelo de tenista e analisou múltiplos fatores fisiológicos, tais como a resistência muscular antes e depois da intervenção. Resultados: Há diferenças consideráveis nos dados de força e resistência musculares de atletas após a terapia física com exercícios. Conclusão: Analisamos as causas do dano muscular a adotamos uma terapia do esporte prática e cientifica. Dessa forma, treinadores e atletas podem encontrar maneiras eficazes de prevenir e manejar lesões musculares; assim, aprimorar o treino esportivo de competição. Nível de evidência ll; Estudos terapêuticos - investigação de resultados de tratamento.
\end{abstract}

Descriptores: Terapia por Exercício; Cotovelo de Tenista; Esportes.

\section{RESUMEN}

Introducción: Varios factores que causan muchos de los traumas en deportes en los grupos que practican actividad deportiva de masa, entrenamiento deportivo amador y entrenamientos deportivos profesionales en China deben ser el centro de nuestra atención. Objetivo: La Terapia Deportiva Científica es un programa de entrenamiento deportivo sistemático formulado para atletas de competición basado en sus características físicas y de sus enfermedades. Métodos: El estudio condujo intervenciones terapéuticas deportivas científicas en pacientes con codo de tenista y analizó múltiples factores fisiológicos, como la resistencia muscular antes y después de la intervención. Resultados: Hay diferencias considerables en los datos de fuerza y resistencia musculares de atletas tras la terapia física con ejercicios. Conclusiones: Analizamos las causas del daño muscular y adoptamos una terapia del deporte práctica y científica. De es a forma, entrenadores y atletas pueden encontrar maneras eficaces de prevenir y manejar lesiones musculares y, así, primorear el entrenamiento deportivo de competición. Nivel de evidencia Il; Estudios terapéuticos - investigación de resultados de tratamiento.

Descriptores: Terapia por Ejercicio; Codo de Tenista; Deportes.

\section{INTRODUCTION}

Tennis elbow (external epicondylitis of the humerus) is a common clinical chronic sports injury. This refers to the inflammation and pain of the tendon at the extensor point of the forearm. The pain is caused by chronic tears caused by repeated exertion of the forearm extensor muscles. Due to frequent activities of the elbow and wrist joints, long-term fatigue causes the starting point of the wrist extensor muscles to be repeatedly stretched and stimulated. ${ }^{1}$ This can cause partial tears and chronic inflammation or local synovial thickening, bursitis, and other changes. People who misuse the elbow in sports, work, and life or have the wrong elbow posture will suffer from tennis elbow. 
At present, the treatment of the tennis elbow mainly includes surgical treatment and non-surgical treatment. In terms of surgical treatment, many scholars have proposed many treatment methods. Such as needle knife relaxation three-step therapy, water needle knife treatment, and so on. But surgical treatment is time-consuming and labor-intensive. ${ }^{2}$ This brings a great economic burden to the patient and brings great pain to the patient's body. Therefore, non-surgical treatment is currently favored by most patients. Non-surgical treatments mainly include physical therapy, ultrasound therapy, light therapy, and exercise therapy. Among them, exercise in exercise therapy is different from general sports. According to their physical conditions and disease characteristics, it is a scientific and reasonable systemic exercise training program formulated for patients. Since exercise therapy has a good recovery effect on the nervous system, cardiovascular system, respiratory system, bone, joint system, etc., it has received more and more attention in the medical and sports circles at home and abroad.

\section{METHODS}

\section{General information}

We selected 25 tennis elbow patients diagnosed by the hospital as the research objects. Among them, 18 were male patients, and 7 were female patients.

\section{Research methods}

We have formulated a 45-day, three-stage sports rehabilitation exercise program. The experiment uses exercise therapy to treat patients.

The first phase lasts for 15 days. The frequency of exercise therapy once every three days is five times in total. This stage is mainly to relieve the patient's pain. ${ }^{3}$

(1) The surgeon's attending doctor holds the patient's elbow joint with his right hand, and his left-hand holds the patient's wrist joint. The doctor flexed the patient's elbow joint to $60^{\circ}$, rested for 6 seconds, and restored it. Each set 6 times, repeat five sets. Each group has an interval of $3 \mathrm{~min}$. (2) The surgeon's attending doctor holds the patient's elbow joint with his right hand, and his left hand holds the patient's wrist joint.

The second phase lasts for 15 days. Exercise treatment once every three days. This stage mainly restores the patient's muscle strength and function.

(1) A stretch of the elastic band is wrapped around the patient's palm, and the other end of the elastic band is placed under the patient's feet for fixation. The patient's elbow joint is placed above the thigh. Stretch the elastic band to bend the elbow joint to $30^{\circ}$, rest for 6 seconds to restore. Each group has eight reps, a total of 3 groups. Each group has an interval of $1 \mathrm{~min}$. (2) A stretch of the elastic band is wrapped around the patient's palm, and the other end of the elastic band is placed under the patient's feet for fixation. The patient's affected arm is placed behind the side of the body, and the elastic band is stretched to extend the elbow joint to $180^{\circ}$ and rest for 6 seconds to restore. Each group has eight reps, a total of 3 groups, and each group has an interval of 1 min.

The third stage lasts for 15 days. Exercise treatment once every three days, a total of 5 times. This stage mainly restores muscle proprioception.

(1) A stretch of the elastic band is wrapped around the patient's palm, and the other end of the elastic band is placed under the patient's feet for fixation. The patient's elbow joint was placed on the upper thigh to stretch the elastic band to make the elbow joint bend to $90^{\circ}$, and rest for 6 seconds to restore. ${ }^{4}$ (2) The patient's palm is wrapped with an elastic band, the other end of the elastic band is placed under the patient's feet, and the patient's affected arm is placed behind the body. Stretch the elastic band to extend the elbow joint to $120^{\circ}$, rest for 6 seconds and restore.

No other treatments can be used while the patient is receiving exercise therapy. The patient can no longer perform the vigorous exercise to prevent re-injury to the elbow joint.
According to the definition of Discrete Wavelet Transform DWT, we have

$$
g j, n=\left[g\left(r^{\prime} k, \theta^{\prime}\right), \psi j, n(k)\right]=\sum^{+\infty} g\left(r^{\prime} k, \theta^{\prime}\right) \overline{\psi j, n(k)}
$$

Where: $\overline{\Psi j, n(k)}$ is the duality of wavelet basis $\Psi j, n(k)$. $\{g j, n\}$ represents the wavelet coefficient. The above-mentioned discrete wavelet transform is a one-dimensional discrete wavelet transform. We can use the one-dimensional mallat tower algorithm to decompose and reconstruct it perfectly. ${ }^{5}$ For exercise therapy $g\left(r^{\prime} k, \theta^{\prime}\right)$, we can decompose it into two parts: smooth information $\mathrm{Ljg}$ and detailed information $\mathrm{Hjg}$ :

$$
g=L_{1} g+H_{1} g
$$

Expand by orthogonal basis,

$$
L_{1} g=\sum_{k=0}^{N=1} c_{L}\left(r^{\prime} k, \theta^{\prime}, 1\right) \varphi_{1, n}(k)
$$

$$
H_{1} g=\sum_{k=0}^{N=1} c_{L}\left(r^{\prime} k, \theta^{\prime}, 1\right) \psi_{1, n}(k)
$$

In formula (4), sequence $c_{L}\left(r^{\prime} k, \theta^{\prime}, 1\right)$ represents the smooth approximation part of data $g\left(r^{\prime} k, \theta^{\prime}\right)$, which is defined as:

$c_{L}\left(r^{\prime} k, \theta^{\prime}, 0\right)=g\left(r^{\prime} k, \theta^{\prime}\right)$

To get,

$c_{L}\left(r^{\prime} k, \theta^{\prime}, 1\right)=\sum_{k=0}^{N=1} c_{L}\left(r^{\prime} k, \theta^{\prime}, 0\right) h(k-2 n)=g_{L}\left(n, \theta^{\prime}, 1\right)$

$c_{H}\left(r^{\prime} k, \theta^{\prime}, 1\right)=\sum_{k=0}^{N=1} c_{L}\left(r^{\prime} k, \theta^{\prime}, 0\right) g(k-2 n)=g_{H}\left(n, \theta^{\prime}, 1\right)$

$c_{L}\left(r^{\prime} k, \theta^{\prime}, 1\right)$ and $c_{H}\left(r^{\prime} k, \theta^{\prime}, 1\right)$ are smooth approximation and detailed information, respectively. They are related to $c H\left(r^{\prime} k, \theta^{\prime}, 0\right) . g(n)$ and $h(n)$ are determined by the defined multi-resolution analysis. Then the operators $L$ and $H$ are defined as

$(L c)_{n}=\sum_{k} h(k-2 n) c\left(k, \theta^{\prime}\right)$

$(H c)_{n}=\sum_{k} g(k-2 n) c\left(k, \theta^{\prime}\right)$

Equations (8) and (9) then become

$c_{L}\left(n, \theta^{\prime}, 2\right)=\sum c_{L}\left(r^{\prime} k, \theta^{\prime}, 1\right) h(k-2 n)=g_{L}\left(n, \theta^{\prime}, 2\right)$

$c_{H}\left(n, \theta^{\prime}, 2\right)=\sum_{k} c_{H}\left(r^{\prime} k, \theta^{\prime}, 1\right) g(k-2 n)=g_{H}\left(n, \theta^{\prime}, 2\right)$ 


\section{Statistics}

The measured data is statistically processed with SPSS17.0 software. One-way analysis of variance was used for three consecutive data within the group. Paired-sample T-test was used for two consecutive data. $P<0.05$ is a significant difference.

\section{RESULTS}

\section{Test results and analysis of elbow joint pain before and after the experiment}

After 45 days of exercise therapy for tennis elbow patients, we stretched the patient's elbow. The degree of elbow pain is average. The value of VAS is 4.00. Before treatment, the patient's VAS value was 8.0, and it was excruciating when stretching the elbow. ${ }^{6}$ Before and after the experiment, the patient's VAS value dropped by 4.00 , and the P-value was less than 0.01 .

\section{Test results and analysis of elbow joint function before and after the experiment}

Table 1 shows the functional test results of the elbow joint before and after the experiment. The larger the value, the higher the degree of elbow joint dysfunction.? This shows that the patient's elbow joint dysfunction was reduced after the experiment.

It can be seen from Table 2 that after 45 days of exercise therapy, the scores of the five test actions have decreased to varying degrees. This shows that the elbow function of tennis elbow patients has improved significantly. ${ }^{8}$ There is a significant difference between the data before and after the experiment. That is, exercise therapy has a significant effect on the treatment of tennis elbow.

\section{Test results and analysis of elbow joint range of motion before and after the experiment}

From Table 3, the mobility of the elbow joint of the patient after 45 days of exercise therapy has been dramatically improved. This shows that an elbow joint active stretching exercise can recover the movement of the patient's elbow joint flexion and hyperextension better than that of internal rotation and external rotation. But overall, there is a significant difference in the elbow joint range of motion before and after the elbow joint active stretching experiment.

Table 1. Test results of elbow joint function before and after the experiment.

\begin{tabular}{c|c|c}
\hline \multirow{2}{*}{ Arm bent } & Before the experiment & 25 \\
\cline { 2 - 3 } & After the experiment & 8 \\
\hline \multirow{2}{*}{ Twist the towel } & Before the experiment & 36 \\
\cline { 2 - 3 } & After the experiment & 15 \\
\hline \multirow{2}{*}{ Shot } & Before the experiment & 38 \\
\cline { 2 - 3 } & After the experiment & 13 \\
\hline \multirow{2}{*}{ Backhand hitting tennis } & Before the experiment & 43 \\
\cline { 2 - 3 } & After the experiment & 25 \\
\hline \multirow{2}{*}{ Pick up heavy objects } & Before the experiment & 46 \\
\cline { 2 - 3 } & After the experiment & 18 \\
\hline
\end{tabular}

Table 2. Test results of elbow joint function before and after the experiment.

\begin{tabular}{c|c|c|c|c}
\hline Action & $\begin{array}{c}\text { Before the } \\
\text { experiment }\end{array}$ & $\begin{array}{c}\text { After the } \\
\text { experiment }\end{array}$ & $\mathbf{T}$ & $\mathbf{P}$ \\
\hline Arm bent & $2.00 \pm 0.31$ & $1.00 \pm 0.11$ & 12.16 & $<0.01$ \\
\hline Twist the towel & $2.00 \pm 0.42$ & $1.00 \pm 0.29$ & 13.42 & $<0.01$ \\
\hline Shot & $3,000 \pm 0.45$ & $1.00 \pm 0.21$ & 12.47 & $<0.01$ \\
\hline Backhand hitting tennis & $3.00 \pm 0.48$ & $2.00 \pm 0.59$ & 13.65 & $<0.05$ \\
\hline Pick up heavy objects & $3.00 \pm 0.59$ & $2.00 \pm 0.50$ & 14.3 & $<0.05$ \\
\hline
\end{tabular}

Test results and analysis of elbow muscle strength before and after the experiment

It can be seen from Table 4 that the muscle strength of the elbow joint of tennis elbow patients has been improved after the exercise therapy. In particular, the elbow joint can move freely in flexion and hyperextension. This shows that the muscle strength of the elbow joint is significantly different from that before the experiment.

\section{Test results and analysis of elbow muscle endurance before and after the experiment}

Table 5 shows that the muscular endurance of the elbow joint of tennis elbow patients is significantly enhanced after treatment. This shows that exercise therapy has a significant effect on the recovery of elbow muscle endurance.

\section{Test results and analysis of the deviation of elbow joint pro- prioception before and after the experiment}

Table 6 shows that the deviation of elbow joint proprioception has a certain degree of reduction after treatment compared with before treatment. The test data of flexion and hyperextension is $P<0.01$. This shows that the proprioceptive deviation of the elbow joint flexion is significantly different after treatment.

\section{DISCUSSION}

Exercise therapy can improve the metabolism and blood circulation of the elbow and surrounding tissues, and it can effectively reduce the pain of the elbow of tennis elbow patients. It can be analyzed that the improvement degree of the elbow flexion and hyperextension function

Table 3. Tests of elbow joint range of motion before and after the experiment.

\begin{tabular}{c|c|c|c|c}
\hline Action & $\begin{array}{c}\text { Before the } \\
\text { experiment }\end{array}$ & $\begin{array}{c}\text { After the } \\
\text { experiment }\end{array}$ & $\mathbf{T}$ & $\mathbf{P}$ \\
\hline Bend forward & $60.00 \pm 4.10$ & $125.00 \pm 10.50$ & -18.16 & $<0.01$ \\
\hline Overextension & $2.00 \pm 0.92$ & $8.25 \pm 2.75$ & -14.39 & $<0.01$ \\
\hline Pronation & $25.12 \pm 3.31$ & $56.32 \pm 2.8$ & -16.18 & $<0.05$ \\
\hline External rotation & $21.23 \pm 3.38$ & $61.12 \pm 3.18$ & -8.44 & $<0.05$ \\
\hline
\end{tabular}

Table 4. Test results of the stretch length of the elastic band before and after the experiment.

\begin{tabular}{c|c|c|c|c}
\hline Action & $\begin{array}{c}\text { Before the } \\
\text { experiment }\end{array}$ & After the test & $\mathbf{T}$ & $\mathbf{P}$ \\
\hline Bend forward & $14.23 \pm 4.55$ & $32.03 \pm 5.08$ & -34.24 & $<0.01$ \\
\hline Overextension & $2.12 \pm 1.89$ & $8.02 \pm 1.61$ & -16.94 & $<0.01$ \\
\hline Rotate left & $5.23 \pm 0.56$ & $13.64 \pm 2.88$ & -10 & $<0.01$ \\
\hline Rotate right & $6.32 \pm 0.94$ & $15.02 \pm 3.68$ & -7.58 & $<0.01$ \\
\hline
\end{tabular}

Table 5. Test situation of the stretch time of elastic band before and after the experiment.

\begin{tabular}{c|c|c|c|c}
\hline Action & $\begin{array}{c}\text { Before the } \\
\text { experiment }\end{array}$ & After the test & $\mathbf{T}$ & $\mathbf{P}$ \\
\hline Bend forward & $87.93 \pm 14.55$ & $137.03 \pm 22.08$ & -34.24 & $<0.01$ \\
\hline Overextension & $70.87 \pm 9.89$ & $110.97 \pm 11.61$ & -16.94 & $<0.01$ \\
\hline Pronation & $54.10 \pm 7.37$ & $94.92 \pm 5.88$ & -10 & $<0.05$ \\
\hline External rotation & $55.87 \pm 7.14$ & $86.54 \pm 8.68$ & -7.58 & $<0.05$ \\
\hline
\end{tabular}

Table 6. Proprioception of the elbow joint before and after the experiment

\begin{tabular}{c|c|c|c|c}
\hline Action & $\begin{array}{c}\text { Before the } \\
\text { experiment }\end{array}$ & After the test & $\mathbf{T}$ & $\mathbf{P}$ \\
\hline Bend forward & $5.22 \pm 1.36$ & $2.61 \pm 1.03$ & 9.27 & $<0.01$ \\
\hline Overextension & $3.28 \pm 1.61$ & $1.33 \pm 1.78$ & 3.08 & $<0.01$ \\
\hline Pronation & $5.89 \pm 0.83$ & $5.72 \pm 0.77$ & 1.38 & 0.48 \\
\hline External rotation & $6.06 \pm 0.74$ & $5.61 \pm 0.62$ & 3.06 & 0.44 \\
\hline
\end{tabular}


of the patient before and after the experiment is higher than the improvement degree of the internal rotation and external rotation of the elbow joint. That is to say, the recovery effect of exercise therapy on the patient's elbow joint flexion and hyperextension is better than the recovery of elbow joint internal rotation and external rotation.

\section{CONCLUSION}

In tennis elbow patients, the blood circulation and metabolism of the elbow joint have been improved after the passive stretching of the elbow by the surgeon. Pain in the elbow has been significantly reduced. The patient's elbow range of motion recovered significantly after a period of practice with elastic bands and Sailor rods. The exercise of the patient's active stretching of the elastic band and the twisting of the Sailor rod has a significant effect on the improvement of elbow joint function.

The author declare no potential conflict of interest related to this article

\section{REFERENCES}

1. Whittaker JL, Roos EM. A pragmatic approach to prevent post-traumatic osteoarthritis after sport or exercise-related joint injury. Best Pract Res Clin Rheumatol. 2019;33(1):158-71.

2. Saito Y, Chikenji TS, Matsumura T, Nakano M, Fujimiya M. Exercise enhances skeletal muscle regeneration by promoting senescence in fibro-adipogenic progenitors. Nat Commun. 2020;11(1):889.

3. Dos Santos Franco YR, Miyamoto GC, Franco KF, de Oliveira RR, Cabral CM. Exercise therapy in the treatment of tendinopathies of the lower limbs: a protocol of a systematic review. Syst Rev. 2019;8(1):142.

4. Marchenkova LA, Makarova EV. [Exercise therapy and bracing in patients with osteoporotic compression vertebral fractures]. Vopr Kurortol Fizioter Lech Fiz Kult. 2019;96(4):69-75. Russian.

5. Gorgey AS, Khalil RE, Gill R, Gater DR, Lavis TD, Cardozo CP, Adler RA. Low-Dose Testosterone and
Evoked Resistance Exercise after Spinal Cord Injury on Cardio-Metabolic Risk Factors: An Open-Labe Randomized Clinical Trial. J Neurotrauma. 2019;36(18):2631-45.

6. Hansen S, Vaegter HB, Petersen KK. Pretreatment Exercise-induced Hypoalgesia is Associated With Change in Pain and Function After Standardized Exercise Therapy in Painful Knee Osteoarthritis. Clin J Pain. 2020;36(1):16-24.

7. Ishøi L, Krommes K, Husted RS, Juhl CB, Thorborg K. Diagnosis, prevention and treatment of common lower extremity muscle injuries in sport - grading the evidence: a statement paper commissioned by the Danish Society of Sports Physical Therapy (DSSF). Br J Sports Med. 2020;54(9):528-37.

8. Kim K, Kuang S, Song Q, Gavin TP, Roseguini BT. Impact of heat therapy on recovery after eccentric exercise in humans. J Appl Physiol (1985). 2019;126(4):965-76. 